\title{
MULTI-TEMPORAL DYNAMICS OF LAND USE PATTERNS IN A SITE OF COMMUNITY IMPORTANCE IN SOUTHERN ITALY
}

\author{
RICCA, N. ${ }^{1}$ - GUAGLIARDI, I. ${ }^{2 *}$ \\ ${ }^{I}$ National Research Council of Italy - Institute for Agricultural and Forest Systems in the \\ Mediterranean (ISAFOM) \\ Via Cavour 4/6 - 87036 Rende (CS), Italy \\ (phone: +39-0984-841474; fax: +39-0984-841457; e-mail: nicola.ricca@cnr.it) \\ ${ }^{2}$ Department of Biology, Ecology and Earth Sciences - DiBEST, University of Calabria,Ponte \\ Ponte Bucci, 87036 Rende (CS), - Italy \\ (phone: +39-0984-493635; fax: +39-0984-841457) \\ *Corresponding author \\ e-mail: ilaria.guagliardi@unical.it \\ (Received $3^{\text {rd }}$ Sep 2014; accepted $20^{\text {th }}$ Dec 2014)
}

\begin{abstract}
The importance of surveying a Site of Community Importance (SIC) lies in ensuring the maintenance of natural habitats of threatened or rare species of flora and fauna. This paper addresses the importance of gathering information on landscape changes for improved estimates of the development and dynamics within a European Union SIC in southern Italy. The main objective is to study spatial and temporal change over the last 50 years, in order to identify the characteristics of change and development and find potentially more sustainable systems of land use. The spatio-temporal changes of agro-forestry and urban conditions were investigated by comparing aerial photographs and through GIS spatial analysis. Landscape heterogeneity obviously changed from 1954 to 2001 . The changing patterns in the landscape are the results of long-term interaction between people and nature. The unprecedented growth in the human population in the last centuries translates into increased resource consumption, as manifested in high rates of agriculture and food production, and urbanization, which increased from about 0.9 hectares in 1954-55, to 120 hectares in 2001. Conversely, important elements of the landscape ecology declined by 115 hectares. The proposed study will allow landscape planners to access ecological information through a readily accessible visual format.
\end{abstract}

Keywords: land use change; landscape index; sustainable development

\section{Introduction}

Landscape ecology has become one of the most rapidly developing ecological fields worldwide (Forman and Godron, 1986; Huang et al., 2009; Jorgensen, 2011; Turner, 1989; Urban et al., 1987) due to importance to recognize and understand land-cover (biophysical attributes of the earth's surface) and land use (human purpose or intervention applied to these attributes) changes as the major ecological processes affect and are affected by the dynamic interaction of ecosystems (Wilson and Weng, 2011). In the last few decades there has been a degeneration of natural environments both quantitatively and qualitatively, due to continuous urban development (Guagliardi et al., 2012). Thus the need to colonize areas which previously were functional to the environment and ecosystems has expanded. Urbanization, industrialization, and intensive agriculture result, therefore, in rapid landscape change (Muñoz-Rojas et al., 2011; Xie et al., 2012), in loss of ecological capacities; moreover they threaten biodiversity through habitat destruction, and lead to the destruction of natural beauty and historically valuable cultural landscapes, through fragmentation and degradation 
(Kim and Pauleit, 2005). It is well known that changing land use affects onsite landscape properties, for example soil degradation, and increased erosion after deforestation (Schoorl and Veldkamp, 2001). Progressive urban development has led to the loss of the natural environment (Guagliardi et al., 2013c; Zhao et al., 2010), up to the point where man's survival is brought into question. Indeed, by destroying natural habitats man, without realizing it, brings about an obvious decline in the quality of life. For instance, in Calabria, the poor socio-economic management of mountain areas has resulted in the depopulation of these territories with serious environmental consequences. The growing demands of society for productive, ecologically healthy and attractive multifunctional landscapes require new directions and rethinking of landscape planning and management (Bastian et al., 2006).

Recognizing and understanding landscape dynamics as a historical legacy of disturbance is necessary for the sustainable management of ecosystems (Kadiogullari and Başkent, 2008; Yin and Qing, 2010). Using the lens of sustainability science, landscape researchers and practitioners are breaking new ground regarding how people's values, behaviors, and actions influence the structure, function, and change of designed landscapes in an urbanizing world (Musacchio, 2009). For this reason, this surge in interest in landscape ecology is also shown in recent efforts to include a landscape perspective in policies and guidelines for managing public lands (McGarigal and Marks, 1995). Therefore, the study of the temporal changes of spatial patterns in landscapes is important not only to understand how a community has been able to evolve and adapt to new scenarios, which have an impact on the stability of a biocenosis but, more importantly, to allow a better understanding of how human activities can be decisive in arresting the regressive processes of ecosystems, and to improve sustainable management, through laws, regulations, the establishment of National Parks and Biogenetic Reserves, areas of protection and so on. This is important especially in Calabria, which represents an active area in a typical upland Mediterranean environment, in continuous changing due to its geological, geomorphological, climatic, and human pressure characteristics that are common to these of the whole Mediterranean areas (Guagliardi et al., 2013a).

Landscape change analyses focus on the identification of long-term dynamics which, as well represented in Calabria, are rarely just simple conversion from one type to another, but rather continuous transitions of land characteristics (Buttafuoco et al., 2010) through cyclical, linear, secular and reversible processes with variable time-lags (Antrop, 1998; Bürgi and Russell, 2001; Coppin et al., 2004). These evolving dynamics can be known by using of multi-temporal analysis, which can illustrate the change in land cover and consequently the compositional variation; therefore, it becomes possible to open up important scenarios of study related to the planning of the development of human activities such as industries, transportation networks, urban fabric, without penalizing the agricultural and forestry resources and ecological elements. In addition, it becomes possible to create gradient and exposure maps which allow us to consider also the physical and topographic variables, and therefore to determine the factors which influence the ecological dynamics, i.e., how a biocenosis can be influenced by low or abrupt gradients, slope exposure, closeness to urban centers or water sources.

Hence, the use of new and increasingly powerful software allows us to create maps which can be overlaid (Map Overlay) in order to generate matrices showing the changes in land use over time, i.e. the gains or the losses of each land use class. The metrics of landscape represent a very important factor in landscape ecology and spatial planning. 
The objective of this study is to analyze and interpret the landscape dynamics in agro-forestry and urban systems of the lower Trionto catchment, in southern Italy. This site was selected for the Mediterranean bio-geographical region, in the Sites of Community Importance (SCI), defined in the European Commission Habitats Directive 92/43/EEC (CEC, 1992) as "a site which, in the bio-geographical region or regions to which it belongs, contributes significantly to the maintenance or restoration at a favorable conservation status of a natural habitat type in Annex I or of a species in Annex II and may also contribute significantly to the coherence of Nature 2000 referred to in Article 3, and/or contributes significantly to the maintenance of biological diversity within the biogeographic region or regions concerned". The study involves a multi-temporal analysis of land cover and use changes over a period of 47 years (1954-2001) through patterns of landscape diversity in response to urbanization and their correlations with other parameters of landscape aspects, such as patch density, edge density and area weight. This study, supported by quantitative assessments, will lead to a deeper and more robust understanding of land-use and land-cover change and to more appropriate policy intervention. Improved understanding is also required to assess and project the future role of land-use and land-cover change in the functioning of the Earth System.

\section{Materials and Methods}

\section{Study area}

The study area, selected for the temporal analysis of landscape dynamics, is located in the Sila Massif,north-western Calabria, between the estuary of the river Trionto to the north, close the built-up area of Mirto Crosia, and its confluence with the stream Laurenzana to the south, in the villages of Caloveto to the east and of Cropalati to the west: this area delineates the natural limits of the basin (Fig. 1). Its SCI name is "Fiumara Trionto" and its SCI code is "IT9310047" (Decreto 7 Marzo 2012).

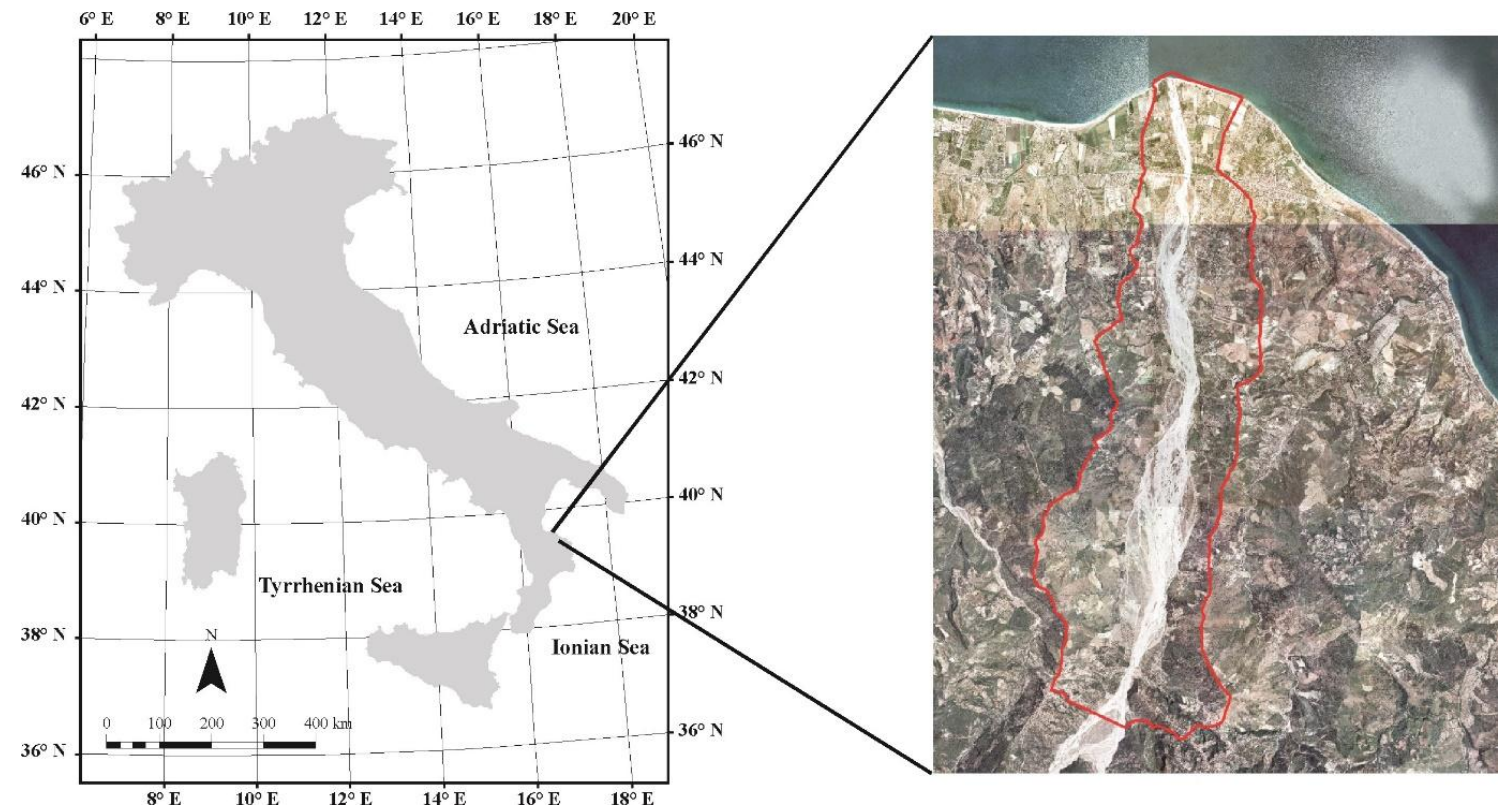

Figure 1. Location of the study area 
In the study area, the lower part of the Trionto catchment from the confluence of the River Laurenzana to the mouth of the estuary was examined; its maximum altitude (Hmax) is 407 meters and its medium altitude (Hmed) is 133.8 meters. The area is included in sheets of Italian Institute of Military Geography n. 545 "Trionto" and n. 553 "Caloveto".

Soils and stream sediments of the study area are developed over Sila batholith made up of granitoid and gneissic rocks (Upper Paleozoic and Paloezoic), phyllites, schists and ophiolitic rocks (Cretaceous to Paleozoic) (Guagliardi et al., 2013b) overlapped by sedimentary clastics (Recent to Tortonian).

The river bed consists of alluvial deposits, cobblestones and sand. The Mirto Crosia village and the area close to the estuary are located on artificially fixed alluvial deposits or on vegetation. The innermost part of area consists of conglomerates and slightly consolidated sands, easily disjointed and with high permeability and subordinate clay intervals. Climatically, the area is included in the thermo-Mediterranean range with a hot and sub-humid climate (Bernetti, 1995).

\section{Analysis of multi-temporal land use patterns}

The analysis of the multi-temporal land use variations of the Trionto catchment was conducted through the techniques of photo interpretation, georeferencing, rectification and mosaicing of aerial photographs. Black and white photographs were studied for the periods 1954-55, 1983 and 2001.

Landscape elements (patches) were digitized as lines and polygons in layers corresponding to different years and categories. The aerial photographs were digitized and analyzed and the visualization and the processing of spatial data were carried out by ArcGIS 9.2 Software (ESRI, 2006), whereas the georeferencing, mosaicing and orthorectification of the photos were carried out using ER Mapper 6.4 Software (Earth Resource Mapping, 2003).

The development of GIS (Geographical Information Systems) technology, in particular, has widened the variety of analytical tools available for analyzing and managing landscapes (Hua et al., 2010; Käyhkö et al., 2011; McGarigal and Marks, 1995; Wang et al., 2010). Indeed, the variables which represent the structure and the complexity of the landscape were quantified through a suitable extension for ArcGIS (Patch Analyst).

The integration of the data set with field validation led to the development of an upto-date land use map.

For the classification of different types of land use, Corine Land Cover (CLC50), with IV level of definition, was applied, in order to obtain a univocal classification, albeit with some changes to create a better fit for the area and the scale studied.

To promote the development of landscape ecology and quantitative research, various indices and landscape pattern models were introduced (Apart et al., 2002; Baker and Cal, 1992; Liding et al., 2008; Pearson, 2002; Raines, 2002). Landscape pattern indices are common tools of landscape ecology that are applied with freely available software (Corry, 2004). These indices express the complexity for each class of land use and can be of assistance in quantifying the fragmentation process.

Among the metrics which characterize the landscape from a structural and functional point of view, those considered in this study are shown in Table 1. 
Table 1. List and description of class level metrics used in the study

\begin{tabular}{|c|c|c|}
\hline Index Class & Index & Description \\
\hline \multirow[t]{2}{*}{ Patch Density \& Metrics } & Number of Patches (NP) & $\begin{array}{c}\text { Number of patches at the class } \\
\text { level }\end{array}$ \\
\hline & Mean Patch Size (MPS) & Average patch size for a class \\
\hline \multirow[t]{2}{*}{ Shape Metrics } & Mean Shape Index (MSI) & $\begin{array}{l}\text { Deviation of each patch from } \\
\text { circular: a circle has a shape } \\
\text { index value of } 1.0, \text { whereas } \\
\text { fragments with irregular shapes } \\
\text { will have higher values. }\end{array}$ \\
\hline & $\begin{array}{c}\text { Area Weighted Mean Shape } \\
\text { Index (AWMSI) }\end{array}$ & $\begin{array}{l}\text { Average patch characteristic } \\
\text { for a cell selected at random }\end{array}$ \\
\hline \multirow{3}{*}{ Edge Metrics } & Total Edge (TE) & $\begin{array}{c}\text { Total length }(\mathrm{m}) \text { of edge of a } \\
\text { particular patch type (class } \\
\text { level) }\end{array}$ \\
\hline & Edge Density (ED) & $\begin{array}{c}\text { Density (m/ha) of edge of a } \\
\text { particular patch type (class } \\
\text { level) }\end{array}$ \\
\hline & Mean Patch Edge (MPE) & $\begin{array}{l}\text { Average amount of edge per } \\
\text { patch }\end{array}$ \\
\hline \multirow[t]{4}{*}{ Diversity Metrics } & $\begin{array}{c}\text { Shannon's Diversity Index } \\
\text { (SHDI) }\end{array}$ & $\begin{array}{l}\text { Measure of relative patch } \\
\text { diversity. It is a relative } \\
\text { measure of patch diversity. The } \\
\text { index will equal zero when } \\
\text { there is only one patch in the } \\
\text { landscape and increases as the } \\
\text { number of patch types or } \\
\text { proportional distribution of } \\
\text { patch types increases }\end{array}$ \\
\hline & $\begin{array}{c}\text { Shannon's Evenness Index } \\
\text { (SHEI) }\end{array}$ & $\begin{array}{l}\text { Measure of patch distribution } \\
\text { and abundance. It is equal to } \\
\text { zero when the observed patch } \\
\text { distribution is low and } \\
\text { approaches one when the } \\
\text { distribution of patch types } \\
\text { becomes more even }\end{array}$ \\
\hline & Total Landscape Area (TLA) & $\begin{array}{l}\text { Sum of areas of all patches in } \\
\text { the landscape }\end{array}$ \\
\hline & Class Area (CA) & $\begin{array}{c}\text { Area (ha) of each patch type } \\
\text { (class) }\end{array}$ \\
\hline
\end{tabular}

Clearly, patches are the basic building blocks of categorical patch mosaics and, as such, most metrics derive from the spatial character and distribution of the patches themselves. All patch metrics can be grouped loosely according to the level of heterogeneity (patch, class, landscape) and the aspect of landscape pattern represented and can be summarized at the class or landscape level by using the mean and the area weighted mean.

Although each of these attributes plays an individual role in determining ecological function, they may also interact to influence ecological processes (Collinge, 1996).

At the class and landscape level, some of the metrics quantify landscape composition, while others quantify landscape configuration. Landscape composition and configuration can affect ecological processes independently and interactively. Thus, it is especially important to understand, for each metric, which aspect of landscape pattern is being quantified. 


\section{Results and Discussion}

Based on the research aim and land use status, the study area is divided into 12 landscape types, named according to Corine Land Cover legend: urban fabric, industrial, commercial and transport units, mine, dump and construction sites, arable land, permanent crops, heterogeneous agricultural areas, forests, scrub and/or herbaceous vegetation associations, open space with little or no vegetation, maritime wetlands, inland waters, marine waters. These various landscape types have changed significantly in the last 50 years and the number of landscape patches and patch structure has also changed to different degrees. The land use/cover in 1954-55, 1983 and 2001 are shown in Fig. 2,
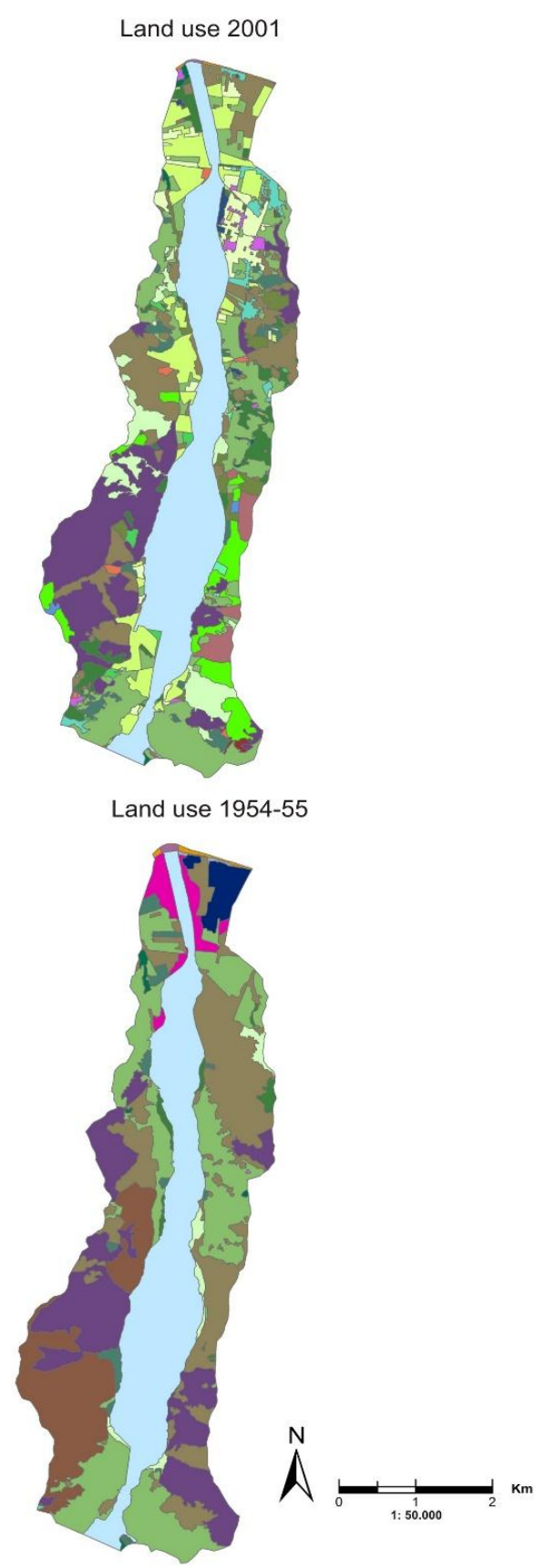

Land use 1983
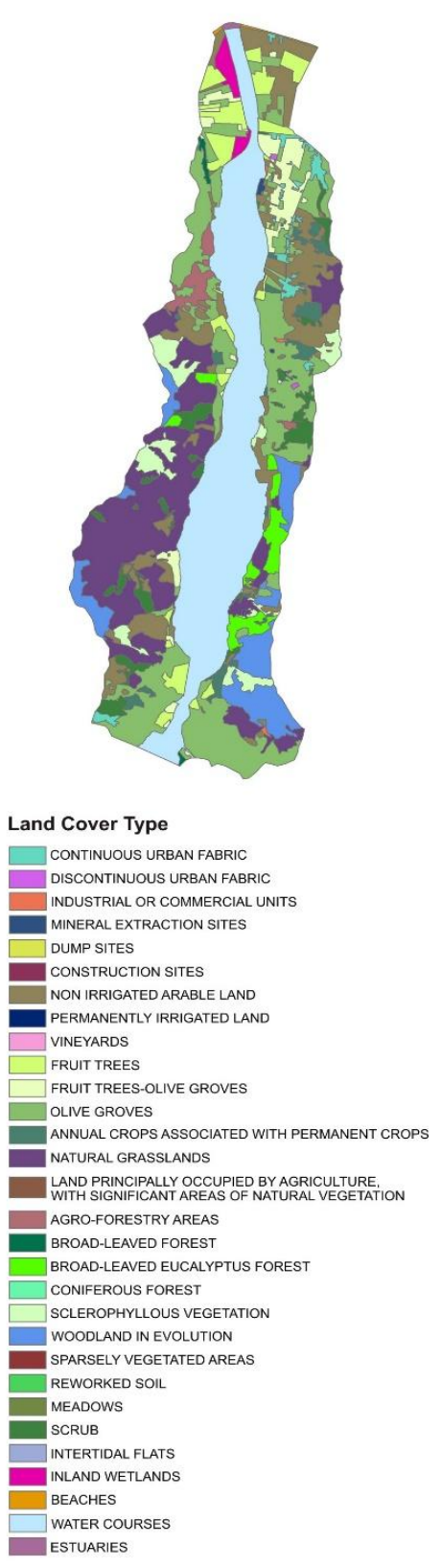

Figure 2. Maps of land use/cover changes in Trionto catchment, 1954-55-2001 
and the quantification of land use change for the analyzed categories is given in Table 2 (in $\mathrm{m}^{2}$ ) and in Table 3 (percentages of increase or decrease of land cover area in 2001 and 1983 compared to 1954-55). From the analysis of land use/cover images, it is notable that, where today there is the built-up area of Mirto, in 1954-55 there was no urbanization and, moreover, in that period, the only two inhabited areas were Crosia and Cropalati villages.

Table 2. Comparison of NP and TLA on three periods analysed

\begin{tabular}{|c|c|c|c|c|c|c|}
\hline \multirow[t]{2}{*}{ Land Cover Type } & \multicolumn{3}{|c|}{ Number of Patch } & \multicolumn{3}{|c|}{ Total Area $\left(\mathbf{m}^{2}\right)$} \\
\hline & $\begin{array}{c}\text { Land use } \\
2001\end{array}$ & $\begin{array}{c}\text { Land use } \\
1983 \\
\end{array}$ & $\begin{array}{c}\text { Land use } \\
1954-55 \\
\end{array}$ & $\begin{array}{c}\text { Land use } \\
2001\end{array}$ & $\begin{array}{c}\text { Land use } \\
1983 \\
\end{array}$ & $\begin{array}{c}\text { Land use } \\
1954-55 \\
\end{array}$ \\
\hline Continuous urban fabric & 10 & 17 & 1 & 538635 & 435740 & 6428 \\
\hline Discontinuous urban fabric & 10 & 2 & 1 & 196099 & 18528 & 3543 \\
\hline Industrial or commercial units & 7 & 3 & 0 & 137586 & 28394 & 0 \\
\hline Mineral extraction sites & 3 & 3 & 0 & 102371 & 35278 & 0 \\
\hline Dump sites & 2 & 0 & 0 & 13742 & 0 & 0 \\
\hline Construction sites & 1 & 0 & 0 & 4023 & 0 & 0 \\
\hline Non irrigated land & 65 & 62 & 39 & 3807750 & 3635174 & 6199311 \\
\hline Permanently irrigated land & 0 & 0 & 2 & 0 & 0 & 646287 \\
\hline Vineyards & 3 & 0 & 0 & 5799 & 0 & 0 \\
\hline Fruit trees & 40 & 24 & 0 & 2819369 & 1377036 & 0 \\
\hline Fruit trees - olive groves & 19 & 18 & 0 & 1085777 & 1036399 & 0 \\
\hline $\begin{array}{l}\text { Olive groves } \\
\text { Annual crop associated with }\end{array}$ & 74 & 48 & 18 & 5243674 & 6379208 & 6802746 \\
\hline $\begin{array}{l}\text { Annual crop associated with } \\
\text { permanent crops }\end{array}$ & 18 & 22 & 13 & 672667 & 638196 & 544163 \\
\hline $\begin{array}{l}\text { Natural grasslands } \\
\text { Land principally occupied by } \\
\text { agriculture, with significant } \\
\text { areas of natural vegetation }\end{array}$ & 13 & 13 & 8 & 4756396 & 5442707 & 5026653 \\
\hline Agro-forestry areas & 4 & 3 & 0 & 568954 & 417986 & 0 \\
\hline $\begin{array}{l}\text { Broad-leaved forest } \\
\text { Brod-leaved }\end{array}$ & 7 & 3 & 4 & 104523 & 80813 & 105932 \\
\hline forest & 10 & 7 & 0 & 1385482 & 753657 & 0 \\
\hline Coniferous forest & 3 & 0 & 0 & 52552 & 0 & 0 \\
\hline Sclerophyllous vegetation & 14 & 10 & 6 & 1485277 & 1084585 & 432227 \\
\hline Woodland in evolution & 2 & 7 & 0 & 59094 & 1966756 & 0 \\
\hline Sparsely vegetated areas & 1 & 0 & 0 & 53700 & 0 & 0 \\
\hline Reworked soil & 14 & 0 & 0 & 213623 & 0 & 0 \\
\hline Meadows & 11 & 0 & 0 & 651282 & 0 & 0 \\
\hline Scrub & 39 & 26 & 9 & 1292155 & 1162141 & 319960 \\
\hline Intertidial flats & 0 & 0 & 1 & 0 & 0 & 40125 \\
\hline Inland wetlands & 0 & 2 & 5 & 0 & 280226 & 760526 \\
\hline Beaches & 2 & 2 & 2 & 38770 & 39999 & 80832 \\
\hline Water courses & 1 & 1 & 1 & 7773655 & 8234730 & 8094073 \\
\hline Estuaries & 1 & 1 & 1 & 11596 & 26539 & 39655 \\
\hline
\end{tabular}


Table 3. Comparison, in percentages of increase or decrease, of land-cover areas on three periods analysed

\begin{tabular}{|c|c|c|c|c|c|}
\hline \multirow[t]{2}{*}{ Land Cover Type } & \multicolumn{3}{|c|}{ Percentages of the Total Area } & \multicolumn{2}{|c|}{$\begin{array}{c}\text { Increase or decrease of land } \\
\text { cover area compared to 1954-55 } \\
(\%)\end{array}$} \\
\hline & $\begin{array}{l}\text { Land use } \\
2001 \\
\end{array}$ & $\begin{array}{c}\text { Land use } \\
1983 \\
\end{array}$ & $\begin{array}{l}\text { Land use } \\
1954-55 \\
\end{array}$ & Land use 2001 & Land use 1983 \\
\hline Continuous urban fabric & 1,63 & 1,32 & 0,02 & 1,61 & 1,30 \\
\hline Discontinuous urban fabric & 0,59 & 0,06 & 0,01 & 0,58 & 0,05 \\
\hline Industrial or commercial units & 0,42 & 0,09 & 0,00 & 0,42 & 0,09 \\
\hline Mineral extraction sites & 0,31 & 0,11 & 0,00 & 0,31 & 0,11 \\
\hline Dump sites & 0,04 & 0,00 & 0,00 & 0,04 & 0,00 \\
\hline Construction sites & 0,01 & 0,00 & 0,00 & 0,01 & 0,00 \\
\hline Non irrigated land & 11,51 & 10,99 & 18,74 & $-7,23$ & $-7,75$ \\
\hline Permanently irrigated land & 0,00 & 0,00 & 1,95 & $-1,95$ & $-1,95$ \\
\hline Vineyards & 0,02 & 0,00 & 0,00 & 0,02 & 0,00 \\
\hline Fruit trees & 8,52 & 4,16 & 0,00 & 8,52 & 4,16 \\
\hline Fruit trees - olive groves & 3,28 & 3,13 & 0,00 & 3,28 & 3,13 \\
\hline $\begin{array}{c}\text { Olive groves } \\
\text { Annual crop associated with }\end{array}$ & 15,85 & 19,29 & 20,57 & $-4,71$ & $-1,28$ \\
\hline permanent crops & 2,03 & 1,93 & 1,65 & 0,39 & 0,28 \\
\hline $\begin{array}{l}\text { Natural grasslands } \\
\text { Land principally occupied by }\end{array}$ & 14,38 & 16,46 & 15,20 & $-0,82$ & 1,26 \\
\hline $\begin{array}{l}\text { agriculture, with significant } \\
\text { areas of natural vegetation }\end{array}$ & 0,00 & 0,00 & 12,01 & $-12,01$ & $-12,01$ \\
\hline Agro-forestry areas & 1,72 & 1,26 & 0,00 & 1,72 & 1,26 \\
\hline $\begin{array}{l}\text { Broad-leaved forest } \\
\text { Broad-leaved eucalvntus }\end{array}$ & 0,32 & 0,24 & 0,32 & 0,00 & $-0,08$ \\
\hline forest & 4,19 & 2,28 & 0,00 & 4,19 & 2,28 \\
\hline Coniferous forest & 0,16 & 0,00 & 0,00 & 0,16 & 0,00 \\
\hline Sclerophyllous vegetation & 4,49 & 3,28 & 1,31 & 3,18 & 1,97 \\
\hline Woodland in evolution & 0,18 & 5,95 & 0,00 & 0,18 & 5,95 \\
\hline Sparsely vegetated areas & 0,16 & 0,00 & 0,00 & 0,16 & 0,00 \\
\hline Reworked soil & 0,65 & 0,00 & 0,00 & 0,65 & 0,00 \\
\hline Meadows & 1,97 & 0,00 & 0,00 & 1,97 & 0,00 \\
\hline Scrub & 3,91 & 3,51 & 0,97 & 2,94 & 2,55 \\
\hline Intertidial flats & 0,00 & 0,00 & 0,12 & $-0,12$ & $-0,12$ \\
\hline Inland wetlands & 0,00 & 0,85 & 2,30 & $-2,30$ & $-1,45$ \\
\hline Beaches & 0,12 & 0,12 & 0,24 & $-0,13$ & $-0,12$ \\
\hline Water courses & 23,50 & 24,90 & 24,47 & $-0,97$ & 0,43 \\
\hline Estuaries & 0,04 & 0,08 & 0,12 & $-0,08$ & $-0,04$ \\
\hline
\end{tabular}

Other important findings are: the total absence of industrial areas, mining, olive and fruit orchards and eucalyptus groves, whose reforestation began in the sixties, and the presence of two large surface areas, the first of approximately 64 hectares destined to 
watering crops and the second of about 1000 hectares of agricultural land-use with significant areas of natural vegetation and non-watered arable land (Fig. 3).

The surface of the inland marshes, i.e. areas close to watercourses which were flooded more frequently, was also wide: 76 hectares in 1954-55. In the same period, the scrub areas were lower than 1983 and 2001 because in the fifties, the need for available land to cultivate was greater than in succeeding years.

A radical change in the land use occurred in the seventies when the urban area began to expand rapidly. By 1983 the landscape had completely changed, new categories of land use such as orchards, intercropping between olive groves and fruit orchards as well as Eucalyptus groves appeared. The urban fabric of Mirto occupied part of the surface previously cultivated with olive groves and arable crops. In this scenario industrial and mining areas are also to be found. Crops that require irrigation have been totally replaced by crops that do not; agricultural parts with significant natural areas have been degraded, and a wide area is occupied by forests in evolution, the result of cropping and reforestation of Eucalyptus groves (Table 2).

From 1983 to 2001, the continuous and discontinuous urban fabric and all activities connected with the growing population, such as industry and quarrying, landfills, shipyards and reworked soils, increased from about 51 hectares to 120 hectares.

Compared to 1983, in 2001 the surface area occupied by olive groves decreased, while there was an increase in the surface area occupied by the conjunction of fruit orchards and the olive groves, of approximately 149 hectares (Fig. 3). Other important changes occurred such as the marked reduction of coppices, or Eucalyptus groves, as well as the decrease of the watercourse and the total disappearance of the inland marshes, currently occupied by the expansion of fruit orchards.

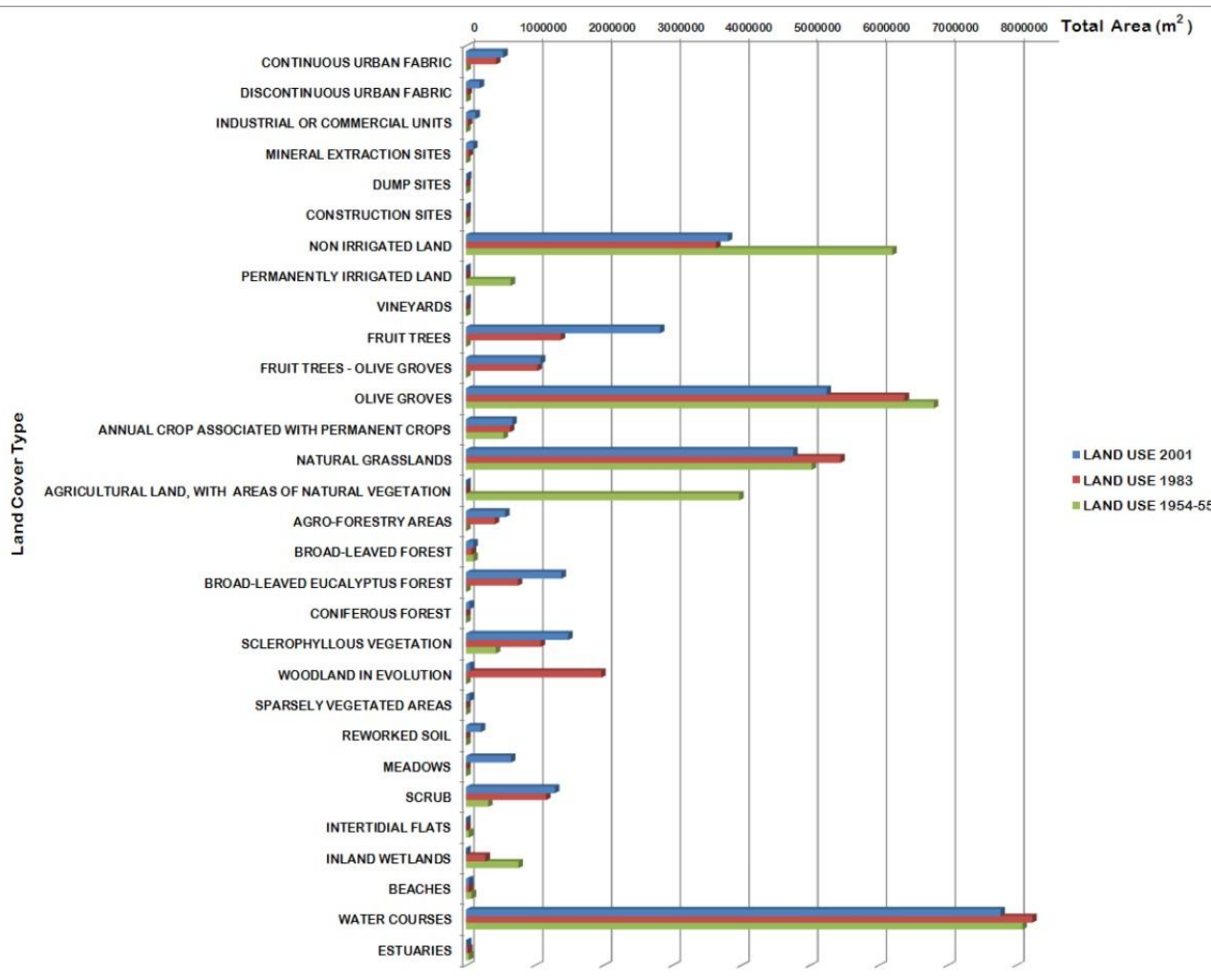

Figure 3. The change of Total Area $\left(\mathrm{m}^{2}\right)$ in land use/cover types over 1954-55 - 2001 
The metric analysis has highlighted the landscape fragmentation, supported by the decrease in the average of the total area of the classes from about 206 hectares in 195455 to approximately 127 hectares in 2001 and together with the increase of the number of patches (NP) from 113 hectares in 1954 to 374 hectares in 2001 (Fig. 4).

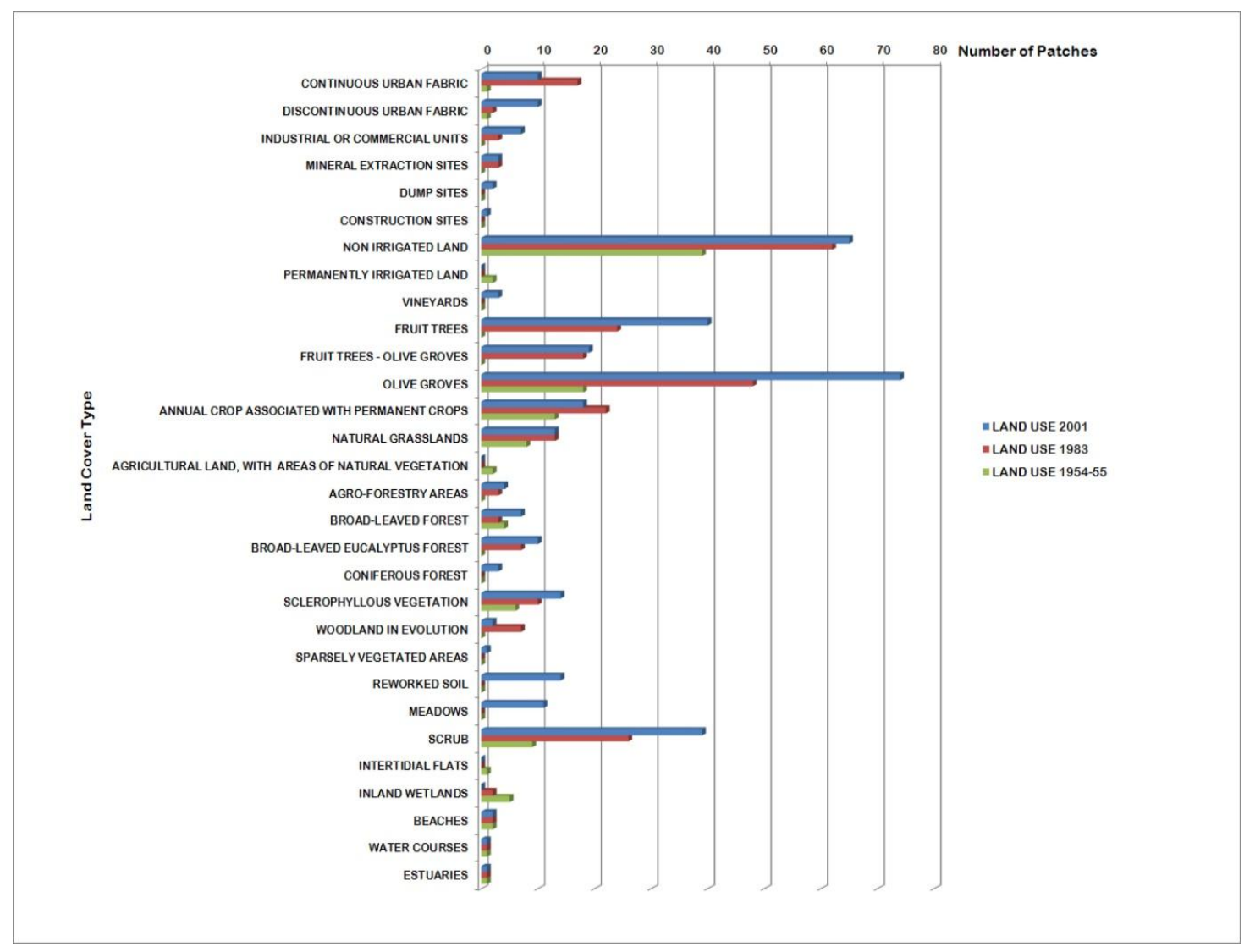

Figure 4. The change of Number of Patches in land use/cover types over 1954-55 - 2001

The Mean Patches Size (MPS) for each class also decreased significantly, as can be concluded from Table 4. The Mean Shape Index (MSI) and the Area Weighted Mean Shape Index (AWMSI) showed a generally increasing trend in the geometric complexity of the patches, especially concerning the non-agricultural and forestry component of land use; however, their values are close to unity the smaller the size of the patch.

Table 4. Analysis of landscape metrics for each land use class on three periods analysed

\begin{tabular}{c|c|c|c|c|c|c|c|c|c}
\hline & \multicolumn{7}{c}{ Land use 2001 } \\
\hline Land Cover Type & AWMSI & $\begin{array}{c}\text { I } \\
\text { I }\end{array}$ & TE & ED & MPE & MPS & NP & TLA & CA \\
\hline Continuous urban fabric & 3,34 & 2,14 & 19048,11 & 5,76 & 1904,81 & 5,39 & 10 & 3307,46 & 53,86 \\
Discontinuous urban fabric & 1,89 & 1,74 & 8430,41 & 2,55 & 843,04 & 1,96 & 10 & 3307,46 & 19,61 \\
Industrial or commercial & 1,51 & 1,59 & 5154,87 & 1,56 & 736,41 & 1,97 & 7 & 3307,46 & 13,76 \\
units & 2,04 & 1,76 & 3431,64 & 1,04 & 1143,88 & 3,41 & 3 & 3307,46 & 10,24 \\
Mineral extraction sites & 1,37 & 1,39 & 780,64 & 0,24 & 390,32 & 0,69 & 2 & 3307,46 & 1,37
\end{tabular}




\begin{tabular}{|c|c|c|c|c|c|c|c|c|c|}
\hline Construction sites & 1,80 & 1,80 & 405,06 & 0,12 & 405,06 & 0,40 & 1 & 3307,46 & 0,40 \\
\hline Non irrigated land & 2,29 & 1,60 & 72840,64 & 22,02 & 1120,63 & 5,86 & 65 & 3307,46 & 380,7 \\
\hline Vineyards & 1,23 & 1,26 & 573,97 & 0,17 & 191,32 & 0,19 & 3 & 3307,46 & 0,58 \\
\hline Fruit trees & 1,68 & 1,45 & 46426,46 & 14,04 & 1160,66 & 7,05 & 40 & 3307,46 & 281,9 \\
\hline Fruit trees - olive groves & 3,35 & 1,65 & 27560,78 & 8,33 & 1450,57 & 5,71 & 19 & 3307,46 & 108,5 \\
\hline Olive groves & 2,49 & 1,64 & 98723,18 & 29,85 & 1334,10 & 7,09 & 74 & 3307,46 & 524,3 \\
\hline $\begin{array}{l}\text { Annual crop associated } \\
\text { with permanent crops }\end{array}$ & 1,88 & 1,65 & 19791,86 & 5,98 & 1099,55 & 3,74 & 18 & 3307,46 & 67,27 \\
\hline Natural grasslands & 2,63 & 2,16 & 54833,41 & 16,58 & 4217,95 & 36,59 & 13 & 3307,46 & 475,6 \\
\hline Agro-forestry areas & 1,57 & 1,54 & 7743,86 & 2,34 & 1935,97 & 14,22 & 4 & 3307,46 & 56,90 \\
\hline Broad-leaved forest & 1,86 & 1,74 & 5053,25 & 1,53 & 721,89 & 1,49 & 7 & 3307,46 & 10,45 \\
\hline forest & 1,98 & 1,71 & 22305,28 & 6,74 & 2230,53 & 13,85 & 10 & 3307,46 & 138,5 \\
\hline Coniferous forest & 1,42 & 1,53 & 1955,22 & 0,59 & 651,74 & 1,75 & 3 & 3307,46 & 5,26 \\
\hline Sclerophyllous vegetation & 2,31 & 2,01 & 27679,35 & 8,37 & 1977,10 & 10,61 & 14 & 3307,46 & 148,5 \\
\hline Woodland in evolution & 1,50 & 1,50 & 1827,76 & 0,55 & 913,88 & 2,95 & 2 & 3307,46 & 5,91 \\
\hline Sparsely vegetated areas & 2,64 & 2,64 & 2169,54 & 0,66 & 2169,54 & 5,37 & 1 & 3307,46 & 5,37 \\
\hline Reworked soil & 1,62 & 1,53 & 8417,74 & 2,55 & 601,27 & 1,53 & 14 & 3307,46 & 21,36 \\
\hline Meadows & 1,93 & 1,79 & 15970,49 & 4,83 & 1451,86 & 5,92 & 11 & 3307,46 & 65,13 \\
\hline Scrub & 2,38 & 1,75 & 39860,48 & 12,05 & 1022,06 & 3,31 & 39 & 3307,46 & 129,2 \\
\hline Beaches & 3,80 & 2,89 & 3145,00 & 0,95 & 1572,50 & 1,94 & 2 & 3307,46 & 3,88 \\
\hline Water courses & 1,93 & 1,93 & 738,59 & 0,22 & 738,59 & 1,16 & 1 & 3307,46 & 1,16 \\
\hline Estuaries & 3,23 & 3,23 & 31889,16 & 9,64 & 31889,16 & 777,3 & 1 & 3307,46 & 777,3 \\
\hline & \multicolumn{9}{|c|}{ Land use 1983} \\
\hline Land Cover Type & AWMSI & $\begin{array}{c}\text { MS } \\
\text { I }\end{array}$ & TE & ED & MPE & MPS & NP & TLA & CA \\
\hline Continuous urban fabric & 3,40 & 1,87 & 18570,06 & 5,61 & 1092,36 & 2,56 & 17 & 3307,41 & 43,57 \\
\hline Discontinuous urban fabric & 1,32 & 1,31 & 895,37 & 0,27 & 447,68 & 0,93 & 2 & 3307,41 & 1,85 \\
\hline units & 1,56 & 1,60 & 1622,91 & 0,49 & 540,97 & 0,95 & 3 & 3307,41 & 2,84 \\
\hline Mineral extraction sites & 1,44 & 1,32 & 1446,35 & 0,44 & 482,12 & 1,18 & 3 & 3307,41 & 3,53 \\
\hline Non irrigated land & 2,67 & 1,65 & 78841,03 & 23,84 & 1271,63 & 5,86 & 62 & 3307,41 & 363,5 \\
\hline Fruit trees & 1,49 & 1,41 & 24820,38 & 7,50 & 1034,18 & 5,74 & 24 & 3307,41 & 137,7 \\
\hline Fruit trees - olive groves & 2,82 & 1,51 & 22880,61 & 6,92 & 1271,14 & 5,76 & 18 & 3307,41 & 103,6 \\
\hline Olive groves & 2,70 & 1,73 & 94624,08 & 28,61 & 1971,34 & 13,29 & 48 & 3307,41 & 637,9 \\
\hline with permanent crops & 1,61 & 1,49 & 18026,99 & 5,45 & 819,41 & 2,90 & 22 & 3307,41 & 63,82 \\
\hline Natural grasslands & 3,18 & 2,02 & 58195,25 & 17,60 & 4476,56 & 41,87 & 13 & 3307,41 & 544,2 \\
\hline Agro-forestry areas & 2,84 & 2,30 & 9263,26 & 2,80 & 3087,75 & 13,93 & 3 & 3307,41 & 41,80 \\
\hline Broad-leaved forest & 2,48 & 2,48 & 4021,37 & 1,22 & 1340,46 & 2,69 & 3 & 3307,41 & 8,08 \\
\hline forest & 1,91 & 1,61 & 13221,55 & 4,00 & 1888,79 & 10,77 & 7 & 3307,41 & 75,37 \\
\hline Sclerophyllous vegetation & 2,21 & 2,14 & 22141,48 & 6,69 & 2214,15 & 10,85 & 10 & 3307,41 & 108,4 \\
\hline Woodland in evolution & 1,90 & 1,84 & 22989,01 & 6,95 & 3284,14 & 28,10 & 7 & 3307,41 & 196,6 \\
\hline Scrub & 2,36 & 2,12 & 36833,64 & 11,14 & 1416,68 & 4,47 & 26 & 3307,41 & 116,2 \\
\hline
\end{tabular}




\begin{tabular}{|c|c|c|c|c|c|c|c|c|c|}
\hline Inland wetlands & 1,73 & 1,79 & 4541,40 & 1,37 & 2270,70 & 14,01 & 2 & 3307,41 & 28,02 \\
\hline Beaches & 3,68 & 2,89 & 3196,67 & 0,97 & 1598,34 & 2,00 & 2 & 3307,41 & 4,00 \\
\hline Water courses & 3,01 & 3,01 & 30615,54 & 9,26 & 30615,54 & 823,47 & 1 & 3307,41 & 823,4 \\
\hline Estuaries & 1,28 & 1,28 & 736,74 & 0,22 & 736,74 & 2,65 & 1 & 3307,41 & 2,65 \\
\hline & \multicolumn{9}{|c|}{ Land use 1954-55 } \\
\hline Land Cover Type & AWMSI & \begin{tabular}{|c|} 
MS \\
I \\
\end{tabular} & TE & ED & MPE & MPS & NP & TLA & CA \\
\hline Continuous urban fabric & 1,30 & 1,30 & 370,41 & 0,11 & 370,41 & 0,64 & 1 & 3307,41 & 0,64 \\
\hline Discontinuous urban fabric & 1,24 & 1,24 & 262,24 & 0,08 & 262,24 & 0,35 & 1 & 3307,41 & 0,35 \\
\hline Non irrigated land & 2,49 & 1,67 & 75141,73 & 22,72 & 1926,71 & 15,90 & 39 & 3307,41 & 619,9 \\
\hline Permanently irrigated land & 1,48 & 1,37 & 5131,75 & 1,55 & 2565,88 & 32,31 & 2 & 3307,41 & 64,63 \\
\hline Olive groves & 2,61 & 1,90 & 70502,16 & 21,32 & 3916,79 & 37,79 & 18 & 3307,41 & 680,2 \\
\hline $\begin{array}{l}\text { Annual crop associated } \\
\text { with permanent crops }\end{array}$ & 1,49 & 1,43 & 12347,21 & 3,73 & 949,79 & 4,19 & 13 & 3307,41 & 54,42 \\
\hline Natural grasslands & 2,09 & 1,99 & 41746,78 & 12,62 & 5218,35 & 62,83 & 8 & 3307,41 & 502,6 \\
\hline $\begin{array}{l}\text { by agriculture, with } \\
\text { significant areas of natural } \\
\text { vegetation }\end{array}$ & 2,71 & 2,51 & 25129,54 & 7,60 & 12564,77 & 198,5 & 2 & 3307,41 & 397,1 \\
\hline Broad-leaved forest & 2,07 & 1,77 & 3951,49 & 1,19 & 987,87 & 2,65 & 4 & 3307,41 & 10,59 \\
\hline Sclerophyllous vegetation & 2,14 & 2,10 & 11680,66 & 3,53 & 1946,78 & 7,20 & 6 & 3307,41 & 43,22 \\
\hline Scrub & 2,04 & 1,98 & 10569,29 & 3,20 & 1174,37 & 3,56 & 9 & 3307,41 & 32,00 \\
\hline Intertidial flats & 4,42 & 4,42 & 3138,20 & 0,95 & 3138,20 & 4,01 & 1 & 3307,41 & 4,01 \\
\hline Inland wetlands & 1,93 & 1,79 & 11723,91 & 3,54 & 2344,78 & 15,21 & 5 & 3307,41 & 76,05 \\
\hline Beaches & 2,82 & 2,19 & 3419,93 & 1,03 & 1709,96 & 4,04 & 2 & 3307,41 & 8,08 \\
\hline Water courses & 2,99 & 2,99 & 30113,37 & 9,10 & 30113,37 & 809,4 & 1 & 3307,41 & 809,4 \\
\hline Estuaries & 1,22 & 1,22 & 858,13 & 0,26 & 858,13 & 3,97 & 1 & 3307,41 & 3,97 \\
\hline
\end{tabular}

Another important element is given by the analysis of indices which quantify the length and the distribution of edges in the landscape Total Edge (TE), Edge Density (ED) and Mean Patch Edge (MPE). The data have revealed that from 1954-55 to 2001, the total perimeter of the patches significantly increased. The ED per hectare increased from 1954-55 to 1983, demonstrating the increase in patch complexity and in the heterogeneity of the mosaic. From 1983 to 2001 the value decreased slightly due to the increasing complexity of the landscape which led to the fusion of the particles and hence a decrease in the value. Considering that the MPE index is the result of the ratio between the total perimeter of each class of land use and the number of patches, it declines with the increase in the number of polygons from 1954-55 to 2001.

The metrics used to describe the whole landscape, namely the Shannon's Diversity Index (SDI) and Shannon's Evenness Index (SEI), showed that, in 1983, there was greater fragmentation and diversification of the types of land use with different extensions compared to 1954-55, whereas from 1983 to 2001, there was a slight decrease in these values, indicating a trend towards simplification, reduction of fragmentation and heterogeneity of territorial spaces (Table 5). 
Table 5. Analysis of Shannon's Diversity Index (SHDI) and the Shannon's Evenness Index (SHEI) on three periods analysed

\begin{tabular}{c|c|c|c}
\hline & $\mathbf{2 0 0 1}$ & $\mathbf{1 9 8 3}$ & $\mathbf{1 9 5 4 - 5 5}$ \\
\hline Shannon Diversity Index & 2,34 & 2,20 & 1,91 \\
Shannon Evenness Index & 0,72 & 0,74 & 0,69 \\
\hline
\end{tabular}

\section{Conclusions}

The present study has shown how, through the use of aerial photographs and image processing software tools, it was possible to analyze the evolutionary dynamics of the changes occurring in a geographical area over 50 years, with particular reference to urban development. The expansion of settlements, development of infrastructure, and extension of industrial areas, which increased from about 0.9 hectares, in 1954-55, to 120 hectares in 2001, reduced the land devoted to agriculture and forestry. Similarly, elements playing an important role in the landscape ecology, such as watercourses, beaches, estuaries and marshes, declined by 115 hectares. The proportion of land used for agriculture and forestry is declining, both for the recent area subtracted in an irreversible way, and for the evolutionary tendency of the study area, especially for the on-going urban development and the settlements in the bed of the Trionto river. In fact, new areas of land are made available for agriculture, violating the safeguards of the Site of Community Importance law and creating a possible flooding hazard. The total abandonment of crop requiring irrigation such as vegetables, the reforestation of the Eucalyptus groves (a native of Australia, which led to a halving of the area available for crops such as grain, hay and so on, without however, achieving the objective for which they were introduced), the increase of fruit orchards, demonstrated how man can determine changes in agroforestry ecosystems, taking into account only of short-term economic needs and undermining the balance between human activities and nature, threatening the survival of many rare and endangered animal and plant species, which require a sustainable management of ecosystems for their survival.

Finally, analysis of spatial and temporal changes in landscape pattern-driven factors could provide valuable scientific basis for regional planning and ecological construction.

\section{REFERENCES}

[1] Antrop, M. (1998): Landscape change: plan or chaos? - Landscape and Urban Planning 41: $155-161$.

[2] Apart, A.A., Raine, S.R. and Paterson, M.S. (2002): Mapping and analysis of changes in the ripariann landscape structure of the Lockyer Valley catchment, Queensland, Australia. - Landscape and Urban Planning 59: 43-57.

[3] Baker, W.L. and Cal, Y. (1992): The rule programs for multiscale analysis of landscape structure using the grass geographical information system. - Landscape Ecology 7: 291302.

[4] Bastian, O., Krönert, R., Lipský, Z. (2006): Landscape diagnosis on different space and time scales - a challenge for landscape planning. - Landscape Ecology 21: 359-374.

[5] Bernetti, G. (1995): Selvicoltura speciale. Torino UTET.

[6] Bürgi, M. and Russell, E.W.B. (2001): Integrative methods to study landscape changes. Land Use Policy 18: 9-16. 
[7] Buttafuoco, G., Castrignanò, A., Colecchia, A.S., Ricca, N. (2010): Delineation of management zones using soil properties and a multivariate geostatistical approach. Italian Journal of Agronomy 4: 323-332.

[8] CEC (Commission of the European Communities) (1992): Council directive 92/43/EEC of 21 May 1992 on the conservation of natural habitats and of wild fauna and flora, Brussels.

[9] Collinge, S.K. (1996): Ecological consequences of habitat fragmentation: implication for landscape architecture and planning. - Landscape and Urban Planning 36: 59-77.

[10] Coppin, P., Jonckheere, I., Nackaerts, K., Muys, B., Lambin, E. (2004): Digital change detection methods in ecosystem monitoring: a review. - International Journal of Remote Sensing 25: 1565-1596.

[11] Corry, R.C. (2004): Characterizing fine-scale patterns of alternative agricultural landscapes with landscape pattern indices. - Landscape Ecology 20: 591-608.

[12] Decreto 7 Marzo 2012. Gazzetta Ufficiale della Repubblica Italiana n. 79 del 3 Aprile 2012: Quinto elenco aggiornato dei siti di importanza comunitaria per la regione biogeografica mediterranea in Italia, ai sensi della Direttiva 92/43/CEE.

[13] Earth Resource Mapping. (2003): ER Mapper 6.4: User guide. Earth Resource Mapping Pty Ltd. San Diego, California, USA.

[14] ESRI. (2006): ArcGIS version 9.2. ESRI, Redlands, California, USA.

[15] Forman, R.T.T. and Godron, M. (1986): Landscape Ecology. - New York, John Wiley \& Sons.

[16] Guagliardi, I., Apollaro, C., Scarciglia, F., De Rosa, R. (2013a): Influence of particle-size on geochemical distribution of stream sediments in the Lese river catchment, southern Italy. - Biotechnologie Agronomie Societe et Environment 17: 43-55.

[17] Guagliardi, I., Buttafuoco, G., Apollaro, C., Bloise, A., De Rosa, R., Cicchella, D. (2013b): Using gamma-ray spectrometry and geostatistics for assessing geochemical behaviour of radioactive elements in the Lese catchment (southern Italy). - International Journal of Environmental Research 7: 645-658.

[18] Guagliardi, I., Buttafuoco, G., Cicchella, D., De Rosa, R. (2013c): A multivariate approach for anomaly separation of potentially toxic trace elements in urban and periurban soils: an application in a southern Italy area. - Journal of Soil and Sediment 13: $117-128$.

[19] Guagliardi, I., Cicchella, D., De Rosa, R. (2012): A geostatistical approach to assess concentration and spatial distribution of heavy metals in urban soils. - Water, Air and Soil Pollution 223: 5983-5998.

[20] Hua, L., Li, X., Tang, L., Yina, K., Zhao, Y. (2010): Spatio-temporal dynamic analysis of an island city landscape: a case study of Xiamen Island, China. - International Journal of Sustainable Development and World Ecology 17: 273-278.

[21] Huang, J., Tu, Z. and Lin, J. (2009): Land-use dynamics and landscape pattern change in a coastal gulf region, southeast China. - International Journal of Sustainable Development and World Ecology 16: 61-66.

[22] Jorgensen, A. (2011): Beyond the view: Future directions in landscape aesthetics research. - Landscape and Urban Planning 100: 353-355.

[23] Kadioğullari, A.I. and Başkent, E.Z. (2008): Spatial and temporal dynamics of land use pattern in Eastern Turkey: a case study in Gümüşhane. - Environmental Monitoring and Assessment 138: 289-303.

[24] Käyhkö, N., Fagerholm, N., Asseid, B.S., Mzee, A.J. (2011): Dynamic land use and land cover changes and their effect on forest resources in a coastal village of Matemwe, Zanzibar, Tanzania. - Land Use Policy 28: 26-37.

[25] Kim, K-H. and Pauleit, S. (2005): Landscape metrics to assess the ecological conditions of city regions: Application to Kwangju City, South Korea. - International Journal of Sustainable Development and World Ecology 12: 227-244. 
[26] Liding, C., Yang, L., Yihe, L., Xiaoming, F., Bojie, F. (2008): Pattern analysis in landscape ecology: progress, challenges and outlook. - Acta Ecologica Sinica 28: 55215531.

[27] McGarigal, K. and Marks, B.J. (1995): FRAGSTATS: spatial pattern analysis program for quantifying landscape structure. Gen. Tech. Rep. PNW-GTR-351. Portland, OR: U.S. Department of Agriculture, Forest Service, Pacific Northwest Research Station.

[28] Muñoz-Rojas, M., De la Rosa, D., Zavala, L.M., Jordán, A., Anaya-Romero, M. (2011): Changes in land cover and vegetation carbon stocks in Andalusia, Southern Spain (19562007). - Science of the Total Environment 409: 2796-2806.

[29] Musacchio, L.R. (2009): The scientific basis for the design of landscape sustainability: A conceptual framework for translational landscape research and practice of designed landscapes and the six Es of landscape sustainability. - Landscape Ecology 24: 9931013.

[30] Pearson, D.M. (2002): The application of local measures of spatial autocorrelation for describing pattern in north Australian landscapes. - Journal of Environmental Management 64: 85-95.

[31] Raines, G.L. (2002): Description and comparison of geologic maps with FRAGSTATS-a spatial statistics program. - Computers \& Geosciences 28: 169-177.

[32] Schoorl, J.M. and Veldkamp, A. (2001): Linking land use and landscape process modelling: a case study for the Álora region (south Spain). - Agriculture, Ecosystems \& Environment 85: 281-292.

[33] Turner, M.G. (1989): Landscape ecology: the effect of pattern on process. - Annual Review of Ecology and Systematics 20: 171-197.

[34] Urban, D.L., O’Neill, R.V., Shugart Jr, H.H. (1987): Landscape ecology: a hierarchical perspective can help scientist understand spatial patterns. - BioScience 37: 119-127.

[35] Wang, S-Y., Liu, J-S., Ma, T-B. (2010): Dynamics and changes in spatial patterns of land use in Yellow River Basin, China. - Land Use Policy 27: 313-323.

[36] Wilson, C.O. and Weng, Q. (2011): Simulating the impacts of future land use and climate changes on surface water quality in the Des Plaines River watershed, Chicago Metropolitan Statistical Area, Illinois. - Science of the Total Environment 409: 43874405.

[37] Xie, Z., Liu, J., Ma, Z., Duan, X., Cui, Y. (2012): Effect of surrounding land-use change on the wetland landscape pattern of a natural protected area in Tianjin, China. International Journal of Sustainable Development and World Ecology 19: 16-24.

[38] Yin, R., Xiang, Q. (2010): An integrative approach to modeling land-use changes: multiple facets of agriculture in the Upper Yangtze basin. - Sustainability Science 5: 918.

[39] Zhao, M., Liu, X., Zheng, B., Zhao, J. (2010): Landscape pattern analysis and management research in the Lugu Lake area. - International Journal of Sustainable Development and World Ecology 15: 36-41. 